\title{
Addendum to 2013 JINS Supplemental Issue 2 Abstracts presented at the INS Mid-year Meeting Amsterdam, The Netherlands, July 10-13, 2013
}

\section{Author changes have been made to the following abstracts:}

\section{Poster Session 6}

- 8. BONILLA, X Neurosyphilis - A Case Study of the Nexus of Severe and Persisting Mental IIIness, Addiction, Homelessness, and Ignorance Authors: L. KHANCHANDANI, X. BONILLA \& S. BINKS, A. Fedio

- 42.FEDIO, AA Quality of Life following Traumatic Brain Injury: The Importance of Family and Friends Authors: A. Fedio, J. Sexton, K. Nirschl, S. Golden, S. Efanov, L. Khanchandani, P. Fedio

\section{The following abstracts were not presented at the meeting:}

\section{Paper Session 5:}

- 6. L.W. BRAGA. Does Literacy Improve Brain Function?

\section{Poster Session 1:}

- 5. O SHEA, D Raven's Advanced Progressive Matrices: An Index For Predicting Inattentional Blindness In Older Adults?

- 6. VALDEZ, P Effects of Simultaneous Performance of Two Tasks on the Indices of Sustained Attention

- 14.LOUGHAN, AR Foundational neuropsychological correlates in the development of mathematics

- $\quad$ 20.FREIRE, T Long Latency Auditory Evoked Potentials (LLAEP) in the Study of Reading and Writing Disorders - A Systematic Review

- 21.GONÇALVES, TD Related Aspects to the Candidate Susceptibility Genes for Developmental Dyslexia: A Systematic Review

\section{Poster Session 2:}

- 7. CHEANG, K A Case Series of Depressed Elderly (>64 years) presenting in a General Hospital in Singapore

- 19.COUTINHO, G Is it possible to identify $\mathrm{MCl}$ and $\mathrm{AD}$ individuals using a 30-minute neuropsychological battery?

- 25.MONTANES, P Neuropsychologial Profiles of Fronto Temporal Dementia and Alzheimer Disease

- 31.MOON, S Gene Interaction and Structural Brain Change in Early-onset Alzheimer's Disease

- 47.OLIVEIRA, RM Disexecutive Mild Cognitive Impairment Predominance in Elderly Assisted at a Geriatric Clinic in a Public Hospital in Rio de Janeiro

- $\quad$ 53.ZANDI, T Identifying vascular dementia risk factors

\section{Poster Session 3:}

- $\quad$ 8. THOMAS, S Paediatric Cerebellar Mutism Syndrome: Challenges to Cognitive Assessment

- $\quad$ 9. THOMAS, SA Parental Perceptions of a Support and Information Group for Parents of Children with Hydrocephalus

- 27.POREH, AM The Rey Auditory Verbal Learning Test Forced Choice Task for the Screening of Malingering

- 34.ANDERSON-HANLEY, C Exercising for Cognitive Health: Virtual versus Outdoor Cycling

- 36.ESLINGER, PJ Cognitive and Mood Effects of Therapeutic Optical Radiation in Long-term Care Residents

- 43.KOLK, A Attention rehabilitation in children with neurological disorders using FORAMENRehab software - efficacy of two different rehabilitation designs

- 47.RIVERO, TS Dissociation between attention and motor control in a video game a training: Prototype data 


\section{Poster Session 4:}

- 1. HORNBERGER, M Fronto-striatal correlates of neuropsychiatric dysfunction in frontotemporal dementia (FTD) and Alzheimer's disease $(A D)$

- 5. LOUGHAN, AR The importance of neuroeducation: Perspectives from special educators

- 11.THISAYAKORM, K Atropine Induced Amnesia in Aged Rats Possibly Due to the Accumulation of AB Production: A Rat Model of Cognitive Impairment Measuring by Operant Behavior

- 16.LUCCHELLI, F Unusual Speech Abnormalities in Behavioural Variant Fronto-Temporal Degeneration: a Single Case Stud

- 31.NAJAS GARCIA, A Executive Functions in Preschoolers with ODD, ADHD and comorbid ODD-ADHD: Evidence from the preschool version of Behavior Rating Inventory of Executive Function (BRIEF-P)

- $\quad$ 32.OKRUSZEK, L Executive Dysfunction in Patients with Frontal Lobe Lesions and in Patients with Schizophrenia: Can We Tell the Difference with Commonly Used Neuropsychological Tests?

- 39.UEHARA, E Preliminary evidence of the reliability and validity of a Brazilian executive function computer task for children: The Circus Magic Cards Game

- 40.VARGENS, FL Children and Adolescents Performance Profile on Executive Function Assessed by NEPSY II

- 48.LEBEDEVA, I Auditory Oddball N100, Single-voxel 1H-MRS and DTI of the Corpus Callosum Genu in Young Male Patients with Schizophrenia

- 49.UNDERHILL, J Does Vermal TMS Decrease the Negative Symptoms of Schizophrenia? A Case Study

\section{Poster Session 5:}

- 14.LAZARUS, T Occipital lobe hemiangioma and Neuro-cognitive findings in recalcitrant substance abuse: A Case Study

- 28.KOZLOVSKIY, SA Neuropsychological Visuo-Spatial Working Memory Tests Performance and Anatomical Characteristics of Hippocampi, Caudate Nuclei and Cingulate Cortex Regions

- 35.VAN DEN BERG, E Meta-analysis of Prospective Memory in Parkinson's Disease

- 37.WITKOWSKA, MA Functioning Of Prospective Memory And Mnemonics Used By Pulmonary Patients

\section{Poster Session 6:}

- 1. GALLAGHER, A Are there modality-specific memory impairments following hippocampal asymmetry in children with temporal lobe epilepsy?

- 18. HOCHMAN COHEN, H The Effect of Cerebellar Mutism on Neuropsychological Functions Among Children With Posterior Fossa Tumors

- 20.BENNETT, E Paediatric brain tumour parent/carer support and information group: An evaluation

- $\quad$ 21.TALBOT, E Encephalitis-Related Sleep Difficulties in the Developing Brain

- 22.TALBOT, E Dancing Eye Syndrome (Myoclonus Opsoclonus Syndrome) in Children: A Case Study

- 41.YANG, C 'Good-old-days' Bias: A Prospective Follow-Up Study to Examine the Pre-Injury Super-Normal Status in Patients with Mild Traumatic Brain Injury

- 44.MARQUEZ DE LA PLATA, C Compromised Structural and Functional Connectivity Among Professional Boxers

- 50.PHILLIPS, A Keeping the mind on the game, and the brain in mind: Concussion care in elite rugby 